\title{
Impact of Sectoral Growth on Unemployment in Nigeria
}

\author{
Obisike, Ndubueze Ezindu ${ }^{1}$, Onwuka, Irene Nkechi ${ }^{2}$, Oluwaseun B. Alade ${ }^{3}$, Udeze, R. Chike ${ }^{4}$ \\ ${ }^{I}$ Department of Economics, Paul University, Awka Anambra State, Nigeria \\ ${ }^{2}$ Department of Economics, Nnamdi Azikiwe University, Awka, Anambra State, Nigeria \\ ${ }^{3}$ Department of Economics, University of Nigeria, Nsukka, Enugu State, Nigeria \\ ${ }^{4}$ Department of Economics, Institute of Ecumenical College of Education Enugu State, Nigeria
}

\begin{abstract}
In every nationthe problem of unemployment is too significant to be ignored as it is necessary in assessing the level of economic activity in a country, and one of the ways with which unemployment problems can be solved is through improvements in sectoral employment. On this note studies on impact of sectoral-unemployment nexus becomes apt. Hence this study examined theimpact of sectoral growth on unemployment in Nigeria from 1997 to 2019. The study adopted OLS technique of analysis and as well subjected the data set to pre-test which include ADF unit root test, co-integration test and error correction mechanism (ECM). Based on the outcomes of the pretest the study analysis was based on short-run estimation.From the results obtained, in the model one only the GRMER sector has the tendency to reduce RUR, in model two GRMAN and GRMER sectors exerted downward pressure on UUR and in model three GDPGR exerted upward pressure on total unemployment rate in Nigeria. From the findings of the study, we therefore conclude that government should refocus on the development of the manufacturing and merchandise sectors which are the hub of industrialisation and marketing. Government should partner with local communities to acquire mass lands that could be bequeathed to beneficiaries for commercial agriculture.
\end{abstract}

Keywords: ECM, GRMER, RUR, GRMAN, UUR, GDPGR.

\section{INTRODUCTION}

$\mathrm{U}$ nemployment rate that is above a digit in any nation is too worrisome to be ignored as it is one of the necessary phenomenon used in assessing the level of economic stabilityof a country. In the case of Nigeria, her unemployment rate poses a threat to her development as it has largely remained in double digits since 2000 . In fact rising unemployment rate in Nigeria has constituted a bane of economic development of the country and in turn has manifested in the rising incidence of social ills among young people due to joblessness.

In addition, it is paramount to understand that the most disturbing phenomenon is that the rising unemployment persisted even in the period of sustained economic growth in Nigeria. For example, while growth rose from $3.4 \%$ in 2005 to $6.9 \%$ and $7.8 \%$ in 2007 and 2010 respectively, unemployment also rose from $11.9 \%$ in 2005 to $12.7 \%$ and $21.1 \%$ in 2007 and 2010 respectively (NBS, 2007;NBS, 2012). Theoretically, economic theory predicts that as the growth trajectory approaches the full employment level, unemployment approaches the non-accelerating inflationary rate of unemployment (NAIRU), which is the natural level of unemployment. However, the Nigerian experience has warranted that the subsisting theory be re-examined so as to ascertain the plausible explanations for the nation's peculiar and disturbing experience.

Nonetheless, unemployment uproars have attracted different dministrations in Nigeria and often in collaboration with the private sector to embark on employment programmes with primary objective of reducing unemployment rate in the country. Some of the programmes thus far includes: National Directorate of Employment (NDE), Small and Medium Enterprises Development Agencies (SMEDAN), the poverty alleviation programme, the Subsidy Reinvestment and Empowerment Programme (SURE-P), and the Youth Enterprise With Innovation in Nigeria (YOUWIN), Better Life Programme, Peoples' Bank, National Agency for Poverty Eradication, (NAPEP), the National open apprenticeship scheme, the graduate job creation loan Guarantee Scheme, and Agricultural sector Employment program. Despite these policies and programmes, unemployment/empowerment remains a major challenge to the developmental process of the Nigeria economy (Salami, 2013).

In order to empirically investigate the reasons for prevalance of persistent unemployment in Nigeria in the face of economic growth, reseachers have tried to subject unemployment rate scenerio in Nigeria to empirical test with many focusing on the impact of economic growth on unemployment rate in the country while few other factored sectors growth in their analysis. For instance, Akpata (2018) examined economicjobless growth nexus in Nigeria and found that Nigeria's aggregate economic growth has negative impact on unemployment in Nigeria. Yahaya and Umar (2017) investigated unemployment-economic growth relationship and found that there is a negative relationship between long run economic growth and unemployment in Nigeria. Jonathan, Anthony and Emily (2015) adopted economic growth as one of the macroeconomic variables in their study and examined the impact of economic growth on unemployment in Nigeria. They found that in the short-run GDP growth rate, among other factors, have positive impact unemployment rate in Nigeria. These stdudies neglected sectors job absorptive 
capacity whereas different sectors may have diferent job carrying capacity, which may suggest that aggreagate growth may not reflect the sectors job absorptive capacity.

Regardless, few scholars in Nigeria have tried to examine sector growth and unemployment rate nexus with more focus on agriculture, industrial and trade sectors. For instance,Ogbanga (2018) assessed the growth of agricultural sector in Nigeria and its impact on employment generation and found that growth of the agricultural and industrial sectors impacted positively on employment generation in Nigeria. Ewubare and Obayori (2015) examined the nexus between real sector performance and unemployment rate in Nigeria. They observed that index of agricultural productivity have significant impact on unemployment rate, while index of industrial productivity has a negative relationship with unemployment rate. Nwaka, Uma and Tuna (2015) analysed the impacts of the trade sector on unemployment rates in Nigeria. They observed that in the long run, real output and income per capita lead to a decline in unemployment, while the trade sector promotes unemployment. Despite the applauded study by the aforementioned scholars their works did not captures other sectors in Nigeria that have strong job absorptive capacity and did not also consider sector spread in terms of job creation. Some sectors spread job creation across rural and urban areas while some are limited to rural or urban areas.

Nevertheless, it has been observed that although sustained and high economic growth could be a panacea for unemployment, the impact route may be rather complex. One of the arguments is that the employment capacity of an economy depends on sectoral labour absorption capacity. This implies that for economic growth to translate to employment, it must be led by a sector with high labour absorption capacity. This requirement is important since unemployment rate could only decline if the rate at which the economy absorbs jobs is higher than the rate at which new entrants enter the labour market. For example, job creation may be more intensive if all sectors are equally experiencing growth.eg agricultural sector is expected to provide jobs for both rural and urban residents. Hence agricultural growth could entail increase in the agricultural productivity through increased number of subsistence farmers. It may also entail increase in productivity through increased farm activities from mechanised farms.

If increased productivity from mechanised farms is labourinduced, unemployment may decline, if it is rather technology-induced, unemployment may rise. Also, through the value chain, agricultural growth may trigger increased demand for agro-allied products, thereby inducing increased demand for labour in such industries. The same is true for key sectors such as Manufacturing, merchandise, oil/gas and services sectors.

Conversely, since economic growth is the horizontal summation of sectoral output growth, it is therefore important to examine the capacity of each key sector to generate employment, or alternatively reduce unemployment. Thus, this need becomes more expedient given that research effort has so far side-lined this approach to unemployment-growth relation.There is no doubt that there is already rich literature on unemployment-growth relation. However, reviewed studies have so far failed to focus on the capacity of the various sectors of the Nigerian economy to reduce unemployment as it grows.

Given the fact that reviewed studies have so far failed to focus on the capacity of the various sectors of the Nigerian economy to reduce unemployment as it grows, coupled with the fact that employment capacity of an economy depends on sectoral growth. The study under review therefore examines the impact of sectoral growth on unemployment reduction in Nigeria. Again, since there are many sectors that make up Nigeria's economy, the sectors under consideration in this study are the key sectors in Nigerian economy such as agriculture, Manufacturing, merchandise, oil/gas and services sectors. Statistically, these sectors have witnessed fluenctuation in growth overtime as unemployment rate prevails, it is therefore paramount to query the changes or growth rate of the sectors with respect to unemployment rate in Nigeria.Further, there is a likelihood that the aforsaid sectors may generate divergent employment in respect of rural and urban unemployment rate. Hence it becomes imparative to examine the impact of growth rate of the aforementioned sectors on rural and urban unemployment rate in Nigeria. Again since sectoral unemployment rate accounts for total unemployment rate and sectoral growth rate accounts for total economic growth rate, it is therefore important to examine the impact of economic growth rate on total unemployment rate in Nigeria. Given these facts, this study fills the knowledge gap in impact of growth rate of the aforementioned sectors on rural and urban unemployment rate and the impact of economic growth rate on total unemployment rate in Nigeria using quarterly data.

\section{Objectives of the Study}

The overall objective of this study was to investigate the impact of sectoral growth on unemployment in Nigeria using the disaggregated approach. Consequently, the specific objectives that guided the study included to:

(i) Examine the the impact of growth rate of agriculture, manufacturing, merchandise, oil/gas and services sectors on urban unemployment rate in Nigeria.

(ii) Ascertain the impact of growth rate of agriculture, manufacturing, merchandise, oil/gas and services sectors on urban unemployment rate in Nigeria.

(iii) Ascertain the impact of economic growth rate on total unemployment rate in Nigeria.

\section{Research Hypotheses}

The study was guided by the following research hypotheses. 
$\mathrm{H}_{01}$ : Growth rate of agriculture, manufacturing, merchandise, oil/gas and services sectors have no significant impact on rural unemployment rate in Nigeria.

$\mathrm{H}_{02}$ : Growth rate of agriculture, manufacturing, merchandise, oil/gas and services sectors have no significant impact on urban unemployment rate in Nigeria.

$\mathrm{H}_{03}$ : Economic growth rate have no significant impact on total unemployment rate in Nigeria

\section{Empirical Literature Review}

On the foreign scene, Duruel and Kara (2016) investigated growth elasticity of employment of different economic sectors in Turkey and tried to determine which sector's growth can create more employment. They formulated a conceptual framework based on neoclassical production functions. They attempted to avoid the criticisms of correlation methodology employed by some other authors, while solving the problems associated with simple formulations, which did not specify the channels through which employment are supposed to affect GDP. Using two-stage least square procedure and annual time series, they found that manufacturing and service sector are more labour elastic than other sectors. The work done by Duruel and Kara show that the relationship between economic growth and unemployment/employment is indirect flowing through the sectors. However the study focused on total unemployment without considering sectoral job absorptive spread in rural and urban areas, again the study was not carried out in Nigeria, hence the need for the study under review which focused not only on sector-unemployment relationship but focused precisely on growth rate of key sectors in Nigeria with respect to rural, urban and total unemployment rate in Nigeria.

Yilmaz (2014) examined the effects of growth of the overall economy on unemployment in Turkey for the period 2010Q1:2013Q3. The variables of the model are unemployment rate, growth rate of real GDP, growth rate of real export and growth rate of real FDI inflows. The method used in the study is the bound testing approach based on autoregressive distributed lag model. The empirical findings indicate, among others, a negative relationship between unemployment and economic growth in Turkey.

Ogbanga (2018) assessed the growth of agricultural sector in Nigeria and its impact on employment generation between 2008 and 2017. The variables of the study were employment rate, gross domestic product, foreign private capital, federal government expenditure and industrial sector output. The study used error correction and Granger Causality methods to analyze the contribution of agricultural sector alongside other explanatory variables on employment generation. The main finding of the study is that growth of the agricultural and industrial sectors impacted positively on employment generation.

\section{RESEARCH METHODS}

\section{Model Specification}

Makun and Nnanna (2015) and Yilmaz (2014)specified an unemployment-economic growth model relationship as thus,

$\mathrm{UNEM}=\mathrm{f}(\mathrm{GDP})$

Where:

$\mathrm{UNEM}=$ Unemployment rate

GDP $=$ Gross domestic product

The present study modified equation 3.7 and adopted a disaggregated approach whereby some sectors that make up the GDP in Nigeria are included in the model as explanatory variables with a few control variables. These sectors include agriculture, manufacturing, merchandise, oil and services. Again since the focus of this study anchors not only on total employment rate and aggregate economic growth but also onrural unemployment rate (RUR), urban unemployment rate (UUR) and growth rate of the aforementioned sectors, the empirical modelsfor this study is specified as;

Model one

RUR = $\mathrm{f}($ GRAGR, GRMAN, GRMER, GROIL, GRSER, FIST, WR)

Model two

UUR $=\mathrm{f}($ GRAGR, GRMAN, GRMER, GROIL, GRSER, FIST, WR)

3.9

Model three

$\mathrm{UNEMR}=\mathrm{f}($ GDPGR, FIST, WR $)$

Where:

UNEMR = Aggregate unemployment rate; GDPGR = GDP growth rate; GRAGR $=$ Growth rate of agricultural sector; GRMAN = Growth rate of manufacturing sector; GRMER = Growth rate of merchandise sector; GROIL = Growth rate of oil/gas sector; GRSER = Growth rate of services sector; FIST $=$ financial distress index and $\mathrm{WR}=$ Minimum wage rate

The econometric forms of the models are specificed as;

Model one

RUR $=x_{0}+x_{1}$ GRAGR $+x_{2}$ GRMAN $+x_{3}$ GRMER + $\chi_{4}$ GROIL $+\chi_{5}$ GRSER $+\chi_{6}$ FIST $+\chi_{7}$ WR $+\varepsilon_{\mathrm{t}} \quad 3.11$

$x_{1} ; x_{2} ; X_{3} ; x_{4}$ and $X_{5}<0 ; x_{6}$ and $X_{7}>0 ; \varepsilon_{\mathrm{t}}=$ error term

Model two

UUR $=\beta_{0}+\beta_{1}$ GRAGR $+\beta_{2}$ GRMAN $+\beta_{3}$ GRMER + $\beta_{4}$ GROIL $+\beta_{5}$ GRSER $+\beta_{6}$ FIST $+\beta_{7}$ WR $+\mu_{\mathrm{t}} \quad 3.12$

$\beta_{1} ; \beta_{2} ; \beta_{3} ; \beta_{4}$ and $\beta_{5}<0 ; \beta_{6}$ and $\beta_{7}>0 ; \mu_{\mathrm{t}}=$ error term

Model three

$\mathrm{UNEMR}=\alpha_{0}+\alpha_{1}$ GDPGR $+\alpha_{2}$ FIST $+\alpha_{3} \mathrm{WR}+\epsilon_{\mathrm{t}}$ 3.13 
$\alpha_{1}<0 ; \alpha_{2}$ and $\alpha_{3}>0 ; €_{\mathrm{t}}=$ error term

\section{RESULT PRESENTATION, ANALYSES AND DISCUSSION OF FINDINGS}

\section{Summary of Unit Root Test Results}

The result of the unit root test is summarised in Table 4.1. The test was conducted using agumented Dickey-Fuller (ADF) method with intercept and trend.

Table 4.1: Unit root test result

\begin{tabular}{|c|c|c|c|c|c|c|}
\hline \multirow{2}{*}{$\begin{array}{l}\text { Variabl } \\
\text { es }\end{array}$} & \multicolumn{3}{|c|}{ Level I $(0)$} & \multicolumn{3}{|c|}{ First difference $\mathrm{I}(1)$} \\
\hline & $\mathrm{ADF}$ & $\begin{array}{c}\text { Critical } \\
5 \% \\
\end{array}$ & $\begin{array}{c}\text { Remark } \\
\mathrm{s}\end{array}$ & $\mathrm{ADF}$ & $\begin{array}{c}\text { Critical } \\
5 \% \\
\end{array}$ & $\begin{array}{c}\text { Remark } \\
\mathrm{s}\end{array}$ \\
\hline \multicolumn{7}{|c|}{ Dependent variable model one } \\
\hline RUR & $\begin{array}{c}- \\
1.35868 \\
1\end{array}$ & $\begin{array}{c}- \\
3.46291 \\
2\end{array}$ & $\begin{array}{c}\text { Do not } \\
\text { reject } \\
\mathrm{H}_{0}\end{array}$ & $\begin{array}{c}- \\
5.50050 \\
3\end{array}$ & $\begin{array}{c}- \\
3.46291 \\
2\end{array}$ & $\begin{array}{c}\text { Reject } \\
\mathrm{H}_{0}\end{array}$ \\
\hline \multicolumn{7}{|c|}{ Dependent variable model two } \\
\hline UUR & $\begin{array}{c}- \\
1.97885 \\
0 \\
\end{array}$ & $\begin{array}{c}- \\
3.46291 \\
2 \\
\end{array}$ & $\begin{array}{c}\text { Do not } \\
\text { reject } \\
\mathrm{H}_{0} \\
\end{array}$ & $\begin{array}{c}- \\
6.58899 \\
1 \\
\end{array}$ & $\begin{array}{c}- \\
3.46291 \\
2 \\
\end{array}$ & $\begin{array}{c}\text { Reject } \\
\mathrm{H}_{0}\end{array}$ \\
\hline \multicolumn{7}{|c|}{ Dependent variable model three } \\
\hline $\begin{array}{c}\text { UNEM } \\
\mathrm{R}\end{array}$ & $\begin{array}{c}- \\
2.27200 \\
4\end{array}$ & $\begin{array}{c}- \\
3.46845 \\
9 \\
\end{array}$ & $\begin{array}{c}\text { Do not } \\
\text { reject } \\
\mathrm{H}_{0} \\
\end{array}$ & $\begin{array}{c}- \\
4.97832 \\
8 \\
\end{array}$ & $\begin{array}{c}- \\
3.46845 \\
9\end{array}$ & $\begin{array}{c}\text { Reject } \\
\mathrm{H}_{0}\end{array}$ \\
\hline \multicolumn{7}{|c|}{ Independent control variables for all the models } \\
\hline FIST & $\begin{array}{c}- \\
1.25970 \\
2 \\
\end{array}$ & $\begin{array}{c}- \\
3.46845 \\
9 \\
\end{array}$ & $\begin{array}{c}\text { Do not } \\
\text { reject } \\
\mathrm{H}_{0} \\
\end{array}$ & $\begin{array}{c}- \\
4.63974 \\
0 \\
\end{array}$ & $\begin{array}{c}- \\
3.46845 \\
9 \\
\end{array}$ & $\begin{array}{c}\text { Reject } \\
\mathrm{H}_{0}\end{array}$ \\
\hline WR & $\begin{array}{c}- \\
2.20216 \\
9 \\
\end{array}$ & $\begin{array}{c}- \\
3.46229 \\
2 \\
\end{array}$ & $\begin{array}{c}\text { Do not } \\
\text { reject } \\
\mathrm{H}_{0} \\
\end{array}$ & $\begin{array}{c}- \\
9.31392 \\
8 \\
\end{array}$ & $\begin{array}{c}- \\
3.46291 \\
2 \\
\end{array}$ & $\begin{array}{c}\text { Reject } \\
\mathrm{H}_{0}\end{array}$ \\
\hline \multicolumn{7}{|c|}{ Independent variable for model one and two } \\
\hline $\begin{array}{c}\text { GRAG } \\
\mathrm{R}\end{array}$ & $\begin{array}{c}- \\
2.07701 \\
6 \\
\end{array}$ & $\begin{array}{c}- \\
3.46486 \\
5 \\
\end{array}$ & $\begin{array}{c}\text { Do not } \\
\text { reject } \\
\mathrm{H}_{0} \\
\end{array}$ & $\begin{array}{c}- \\
9.54651 \\
3 \\
\end{array}$ & $\begin{array}{c}- \\
3.46486 \\
5 \\
\end{array}$ & $\begin{array}{c}\text { Reject } \\
\mathrm{H}_{0}\end{array}$ \\
\hline $\begin{array}{c}\text { GRMA } \\
\mathrm{N}\end{array}$ & $\begin{array}{c}- \\
0.14422 \\
3 \\
\end{array}$ & $\begin{array}{c}- \\
3.46486 \\
5 \\
\end{array}$ & $\begin{array}{c}\text { Do not } \\
\text { reject } \\
\mathrm{H}_{0} \\
\end{array}$ & $\begin{array}{c}- \\
5.61020 \\
8 \\
\end{array}$ & $\begin{array}{c}- \\
3.46486 \\
5 \\
\end{array}$ & $\begin{array}{c}\text { Reject } \\
\mathrm{H}_{0}\end{array}$ \\
\hline $\begin{array}{c}\text { GRME } \\
\mathrm{R}\end{array}$ & $\begin{array}{c}- \\
1.00994 \\
6 \\
\end{array}$ & $\begin{array}{c}- \\
3.46486 \\
5\end{array}$ & $\begin{array}{c}\text { Do not } \\
\text { reject } \\
\mathrm{H}_{0}\end{array}$ & $\begin{array}{c}- \\
10.3519 \\
5 \\
\end{array}$ & $\begin{array}{c}- \\
3.46486 \\
5 \\
\end{array}$ & $\begin{array}{c}\text { Reject } \\
\mathrm{H}_{0}\end{array}$ \\
\hline GROIL & $\begin{array}{c}- \\
2.94206 \\
6\end{array}$ & $\begin{array}{c}- \\
3.46486 \\
5\end{array}$ & $\begin{array}{c}\text { Do not } \\
\text { reject } \\
\mathrm{H}_{0}\end{array}$ & $\begin{array}{c}- \\
5.20892 \\
3 \\
\end{array}$ & $\begin{array}{c}- \\
3.46486 \\
5\end{array}$ & $\begin{array}{c}\text { Reject } \\
\mathrm{H}_{0}\end{array}$ \\
\hline GRSER & $\begin{array}{c}- \\
0.93621 \\
1 \\
\end{array}$ & $\begin{array}{c}- \\
3.46486 \\
5 \\
\end{array}$ & $\begin{array}{c}\text { Do not } \\
\text { reject } \\
\mathrm{H}_{0} \\
\end{array}$ & $\begin{array}{c}- \\
6.07000 \\
2 \\
\end{array}$ & $\begin{array}{c}- \\
3.46486 \\
5 \\
\end{array}$ & $\begin{array}{c}\text { Reject } \\
\mathrm{H}_{0}\end{array}$ \\
\hline \multicolumn{7}{|c|}{ Independent variable for model three } \\
\hline GDPGR & $\begin{array}{c}- \\
1.82134 \\
3 \\
\end{array}$ & $\begin{array}{c}- \\
3.46291 \\
2 \\
\end{array}$ & $\begin{array}{c}\text { Do not } \\
\text { reject } \\
\mathrm{H}_{0} \\
\end{array}$ & $\begin{array}{c}- \\
8.35723 \\
1\end{array}$ & $\begin{array}{c}- \\
3.46291 \\
2 \\
\end{array}$ & $\begin{array}{c}\text { Reject } \\
\mathrm{H}_{0}\end{array}$ \\
\hline
\end{tabular}

Source: Researcher's computations from Eviews 9.

Unit root test hypothesis and decision rule

$\mathrm{H}_{0:}$ The variable has unit root (not stationary)

$\mathrm{H}_{1}$ : The variable has no unit root (stationary)

Decision rule: reject $\mathrm{H}_{0}$ if $\mathrm{ADF}$ is greater than critical value in absolute terms at chosen level of significance.

From unit root test, all the variables in model one and two are stationary at order $\mathrm{I}(\mathrm{I})$, therefore $\mathrm{H}_{0}$ across all the variables and models was rejected, hence the study then concluded that the variables were stationary (the variables had no unit root) in all the models specified. Since all the variables were stationary at order I (I), this study therefore adopted EngelGranger two stage co-integration test in models one and two. First stage of E-G co-integration test states that residual is a level stationary variable and second stage states that there should be at least one co-integrated variable in the equation.

Table 4.2: Residual unit root test

\begin{tabular}{|c|c|c|c|c|}
\hline \multicolumn{5}{|c|}{ Model one } \\
\hline VARIABLE & ADF & $\begin{array}{c}\text { Critical } \\
5 \%\end{array}$ & Order & Remarks \\
\hline Resid01 & -7.3326 & -2.9540 & $\mathrm{I}(0)$ & Reject $\mathrm{H}_{0}$ \\
\hline \multicolumn{5}{|c|}{ Model two } \\
\hline VARIABLE & ADF & $\begin{array}{c}\text { Critical } \\
5 \%\end{array}$ & Order & Remarks \\
\hline Resid02 & -4.0473 & -2.9511 & $\mathrm{I}(0)$ & Reject $\mathrm{H}_{0}$ \\
\hline \multicolumn{5}{|c|}{ Model three } \\
\hline VARIABLE & ADF & $\begin{array}{c}\text { Critical } \\
5 \%\end{array}$ & Order & Remarks \\
\hline Resid02 & -4.0473 & -2.9511 & $\mathrm{I}(0)$ & Reject $\mathrm{H}_{0}$ \\
\hline
\end{tabular}

Source: Authors computation 2019.

Table 4.3: Engel-Granger co-integration test model one

\begin{tabular}{|c|c|c|c|c|}
\hline Dependent & tau-statistic & Prob.* & z-statistic & Prob.* \\
\hline RUR & -2.019559 & 0.9963 & -14.11459 & 0.9661 \\
\hline GRAGR & -3.321604 & $0.0038^{* *}$ & -53.50717 & $0.0070^{* *}$ \\
\hline GRMAN & -3.942787 & 0.5642 & -31.47588 & 0.3515 \\
\hline GRMER & -2.662317 & 0.9683 & -24.28258 & 0.6582 \\
\hline GROIL & -3.369217 & $0.0082^{* *}$ & 42.14651 & $0.0009^{* *}$ \\
\hline GRSER & -3.074312 & 0.9031 & -23.51119 & 0.6947 \\
\hline FIST & -2.885879 & 0.9399 & -14.68155 & 0.9587 \\
\hline WR & -2.056886 & 0.9958 & -9.277454 & 0.9964 \\
\hline
\end{tabular}

** denote co-integration

Source: Authors computation 2019.

Table 4.4: Engel-Granger co-integration test model two

\begin{tabular}{|c|c|c|c|c|}
\hline Dependent & tau-statistic & Prob. $^{*}$ & z-statistic & Prob. $^{*}$ \\
\hline URB & -3.336418 & $0.0287 * *$ & -46.91718 & $0.0303 * *$ \\
\hline GRAGR & -3.572226 & $0.0087 * *$ & -80.00149 & $0.0000 * *$ \\
\hline GRMAN & -3.208843 & 0.8685 & -21.10557 & 0.7909 \\
\hline GRMER & -2.497021 & 0.9811 & -19.81850 & 0.8357 \\
\hline GROIL & -3.515443 & $0.0032^{* *}$ & 35.19400 & $0.0099 * *$ \\
\hline GRSER & -2.955034 & $0.0280^{* *}$ & -20.68284 & $0.0073 * *$ \\
\hline FIST & -2.894727 & 0.9385 & -14.85177 & 0.9563 \\
\hline WR & -2.058085 & 0.9958 & -8.965843 & 0.9970 \\
\hline
\end{tabular}

** denote co-integration.

Source: Authors computation 2019. 
Table 4.5: Engel-Granger co-integration test model three

\begin{tabular}{|c|c|c|c|c|}
\hline Dependent & tau-statistic & Prob. $^{*}$ & z-statistic & Prob.* $^{*}$ \\
\hline UNEM & -2.162378 & 0.8194 & -98.64540 & 0.0000 \\
\hline GDPGR & -4.022272 & $0.0091 * *$ & -33.80976 & $0.0175^{* *}$ \\
\hline FIST & -1.850026 & 0.9064 & -5.703504 & 0.9498 \\
\hline WR & -1.693192 & 0.9352 & -6.445034 & 0.9297 \\
\hline
\end{tabular}

** denote co-integration

Source: Authors computation 2019.

Table 4.2 showed that residual series in equation one, two and three were stationary variables, while tables $4.3,4.4$ and 4.5 indicated that some of the time series in model one, two and three were co-integrated. In model one, there were two cointegrating variables (that is GRAGRand GROIL) as shown in table 4.3. In model two, there were four co-integrating variables (that is URB,GRAGR,GROILand GRSER) as shown in table 4.4, in model three there was one cointegrating variables(that is GDPGR) as shown in table 4.5.

Engel-Granger co-integration test hypothesis and decision rule.

$\mathrm{H}_{0}$ : the variables are not co-integrated

$\mathrm{H}_{1}$ : the variables are co-integrated

Decision rule:

Reject $\mathrm{H}_{0}$ if there is no single co-integrating variable at chosen level of significance and accept $\mathrm{H}_{0}$ if otherwise stated.

Based on our result we rejected $\mathrm{H}_{0}$ which states that there is no single co-integrating variable in the models at $5 \%$ level of significance and accept $\mathrm{H}_{1}$.

Engel-Granger Error Correction Model (Short-run).

Table 4.5 Error correction test

\begin{tabular}{|c|c|c|c|}
\hline \multicolumn{4}{|c|}{ Error correction test } \\
\hline \multicolumn{4}{|c|}{ Model one } \\
\hline Variable & Coefficient & t-statistic & Prob. $^{*}$ \\
\hline ECM01(-1) & -0.110961 & 4.280134 & 0.0000 \\
\hline \multicolumn{4}{|c|}{ Model two } \\
\hline Variable & Coefficient & t-statistic & Prob.* \\
\hline ECM02(-1) & -0.201971 & 14.59130 & 0.0000 \\
\hline \multicolumn{5}{|c|}{ Model three } \\
\hline ECM03(-1) & -0.185082 & 6.617276 & 0.0000 \\
\hline
\end{tabular}

Source: Authors Computation 2018 with E-views 9.

As shown in table 4.5, there existed short-run disequilibrium in model one and two (that is the relationship between rural and urban rates and growth rate of agriculture, manufacturing, merchandise, oil/gas and services sectors in Nigeria) and in model three (that is the relationship between economic growth rate on total unemployment rate in Nigeria). The negative coefficients implied that for the short-run disequilibrium in model one to be corrected in the long run, it would require about $11 \%$ rate of adjustment, while that of model two would require $20.1 \%$ rate of adjustment and the model three would require $18.5 \%$ rate of adjustment. Given the ECM results, the analysis of this study relied on short run result.

\subsubsection{Error Correction Mechanism (ECM) Results (short run)}

Table 4.6: Error correction mechanism for model one and two

\begin{tabular}{|c|c|c|c|c|}
\hline \multirow{2}{*}{$\begin{array}{c}\text { Independ } \\
\text { ent } \\
\text { variables }\end{array}$} & \multicolumn{2}{|c|}{$\begin{array}{c}\text { Model 1: Dependent } \\
\text { variable RUR }\end{array}$} & \multicolumn{2}{c|}{$\begin{array}{c}\text { Model 2: Dependent } \\
\text { variable UUR }\end{array}$} \\
\cline { 2 - 5 } & Coefficient & $\begin{array}{c}\text { T- } \\
\text { statistics }\end{array}$ & Coefficient & $\begin{array}{c}\text { T- } \\
\text { statistics }\end{array}$ \\
\hline ECM(-1) & -0.110961 & 4.280134 & -0.201971 & 14.59130 \\
\hline GRAGR & 3.334364 & 2.466323 & 0.036532 & 1.917093 \\
\hline GRMAN & 0.768974 & $\begin{array}{c}- \\
3.197663\end{array}$ & -0.321342 & $\begin{array}{c}- \\
9.501809\end{array}$ \\
\hline GRMER & -0.021967 & 0.942294 & -0.102393 & - \\
\hline GROIL & 0.086851 & 5.657548 & 0.157982 & 7.517563 \\
\hline GRSER & 0.123763 & - & 0.181096 & 3.365803 \\
\hline FIST & -0.117639 & 2.748576 & 0.026232 & 0.122324 \\
\hline WR & -0.784305 & 1.003501 & -0.456144 & 1.796877 \\
\hline$R^{2}$ & 0.891607 & \multicolumn{2}{|c|}{0.848381} \\
\hline Adj. R $^{2}$ & 0.791515 & \multicolumn{2}{|c|}{8.732830} \\
\hline $\begin{array}{c}\text { F- } \\
\text { Statistic }\end{array}$ & 9.534236 & \multicolumn{2}{|c}{} \\
\hline
\end{tabular}

Source: Researcher's computation from Eview 9 based on study data

The regression estimated in table 4.6 above showed that in model one, growth rate of only the merchandise sector (GRMER) had the tendency to reduce rural unemployment (RUR) in the short run; whereas growth rate of the agricultural (GRAGR), manufacturing (MAN), oil (GROIL) and services (GRSER) sectors had the tendency to increase rural unemployment rate in short run. Reasons for this outcome could be that merchandise activities situate inrural areas of Nigeria, it could also be as a result shift from agricultural activities in rural area tomerchandise activities. Lastly, increase in the control variables, global financial distress (FIST) and minimum wage (WR) showed signs of reducing rural unemployment rate in the short run. All the results were statistically significant at the $5 \%$ level given that their $\mathrm{t}$-ststistics were greater than 2.0 following rule of thumb, except in the case of GRMERand WR whose t-statistic is 0.942294 and 1.003501 respectively.

The model two result shown in Table 4.6 showed that growth rate of the manufacturing and merchandise sectors exerted downward pressure on urban unemployment rate in the short run, whereas growth rate of the agricultural, oil and services sectors exerted upward pressure on urban unemployment rate in the country in the short run. Again, increase in the global financial distress (FIST) exerted positive pressure on urban unemployment rate but increase in the minimum wage rate (WR) was found to drag urban unemployment downwards. Judging from the t-statistics, the results indicated that it was statistically signficant at the 5\% level intuitively, except for GRAGR, FIST and WR whose t-statistics were less than 2.0 by rule of thumb. 
Table 4.7: Error correction mechanism for model three

\begin{tabular}{|c|c|c|}
\hline \multirow{2}{*}{$\begin{array}{c}\text { Independent } \\
\text { variables }\end{array}$} & \multicolumn{2}{|c|}{ Model 3: Dependent variable UNEMP } \\
\cline { 2 - 3 } & Coefficient & T-statistics \\
\hline ECM(-1) & -0.185082 & 6.617276 \\
\hline GDPGR & 0.015275 & 2.718395 \\
\hline FIST & 0.522654 & -3.395759 \\
\hline WR & -1.079005 & 2.866484 \\
\hline $\mathrm{R}^{2}$ & & 0.898609 \\
\hline Adj. $\mathrm{R}^{2}$ & & 0.793663 \\
\hline F-Statistic & \multicolumn{2}{|}{11.06877} \\
\hline
\end{tabular}

Source: Researcher's computation from Eview 9 based on study data

The estimated regression in table 4.7 showed that in the model three, GDP growth rate and FIST had the tendency to increase total unemployment rate in Nigeria in the short run. While WR showed signs of reducing total unemployment rate in the short run. Statistically, all the results were significant at the $5 \%$ level given that their t-ststistics were greater than 2.0 following rule of thumb. However whereas GDPGR and WR were statistically significant positively, FIST was statistically significant negatively.

\section{DISCUSSION OF FINDINGS}

From short run economic criteria estimation of model one of this study, it was observed that only growth rate of the merchandise sector (GRMER) had the tendency to reduce rural unemployment (RUR) within the period of the study.While growth rate of the agricultural (GRAGR), manufacturing (MAN), oil (GROIL) and services (GRSER) sectors had the tendency to increase rural unemployment rate in Nigeria. This could be as a result rural-urban migration which deters agricultural activities as well as manufacturing in rural areas. Again, due to high use oil bio-fuel consumption of fussil fuel was not so high in rural areas hence diminishes oil sector employent capacity rural areas. The outcome of this study was not in tendem with balanced growth theory of Nurkse which posited that simultaneous expansion of all sectors would reduce unemployment rate. Within the period of this study only growth rate of the merchandise sector (GRMER) proved to have the tendency of reducing rural unemployment rate (RUR) in Nigeria. This could result from relative decadence of agricultural sector in rural areas and consequently would give room for merchandisingin rural areas in Nigeria.

From model two short run economic criteria estimationwhich examined the impact of growth rate of agriculture, manufacturing, merchandise, oil/gas and services sectors on urban unemployment rate in Nigeria. It was observed that GRMAN and GRMERhad the tendency to reduce urban unemployment rate (UUR) in Nigeria within the period under study better than GRAGR, GROIL and GRSER sectors. Good number of factors could account for such result; first Nigerian youth wer seeking for quick money ventures or white colar jobs rather than agriculture which its yield were subject to hervest periods. Second, the service sector which cut acrossretail, banks, hotels, real estate, education, health, social work, recreation, media, communications, electricity, and water supply are facing challenges of low salary, delay in payment and priortizing recruitment of O.N.D holders. Third, population presure in urban areas in Nigeria could also contribute low employment in GRAGR, GROIL and GRSER sectors while the spread of manufacturing sector (such as Food, Beverage, Tobacco, Textiles, Leather, and Apparel, Wood, Paper, and Printing, Coal, Chemicals, Plastics and Rubber, Nonmetallic Mineral, Primary Metal, Fabricated Metal, and Machinery and Computer and Electronics) and merchandise sector (such as sale, marketing and shopping) could contribute to employment generation in urban areas in Nigeria. The result obtained in model two of this study was not in tendem with balanced growth theory of Nurkse which submitted that simultaneous expansion of all sectors would reduce unemployment rate.Evidence within the scope of this research work showed that GRMAN and GRMER had the tendency of reducing urban unemployment rate (UUR) in Nigeria better than other sectors considered in the study.

Empirically, the results of this study partly agreed with findings of some of the literatures reviewed despite slight difference in the approach of the studies. Ogbanga (2018) and Ewubare and Obayori (2015)found that growth of the agricultural and industrial sectors contributed positively on employment generation in Nigeria while in current research work growth rate of agricultural sector had not contributed positively on reduction of rural and urban unemployment in Nigeria. Further, Duruel and Kara (2016) found that manufacturing and service sector were more labour elastic than other sectors in Turkey. Evidence from the this research work showed the same for nigeria within the scope of this study and with respect to manufacturing sector, but the reverse helds for the services sector. The deviation could be as a result of administrative, political and socio-economic orientational value.

From model three short run economic criteria estimation which examined the impact of economic growth rate on total unemployment rate in Nigeria. The result obtained revealed that within the period of this study GDPGR did not contribute to reduction of unemployment rate (UEMR) in Nigeria. Rather the result evidence showedthat unemployment rate increased as GDPGR increased.

\section{CONCLUSION AND RECOMMENDATION}

Based on the results obtained, this study therefore concluded that government should refocus on the development of the manufacturing and merchandise sectors which were the hub of industrialisation and marketing and recommended that Government should partner with local communities to acquire mass lands that could be bequeathed to beneficiaries for commercial agriculture. 


\section{REFERENCES}

[1] Ajakaiye, Jerome, Nabena and Alaba (2016). Unemployment and economicgrowthin Nigeria. Journal of Economics and Sustainable Development5(4), 138-144.

[2] Apkata, A. (2018). Structural transformation and jobless growth in Nigeria.PwC Working paper.Available at www.pwc.com/ng.

[3] Central Bank of Nigeria (CBN, 2013). Modelling the real sector of the Nigerian economy. CBN Annual Review.

[4] Duruel, A. \& Kara, M. (2016). Empirical analysis of sectoral growth and employment generation in Turkey. Asian Economic and Financial Review7(10), 1598-1608.

[5] Enilolobo1,O.S.,Mustapha,S. A. \&Ikechukwu, O. P. (2019).Nexus between agriculture and unemployment in Nigeria.Journal of Economics, Management and Trade 22(5), 1-13. Article no. 46948.

[6] Ewubare, D. B. \& Obayori, J. B. (2015). The real sector performance and unemployment rate in Nigeria. British Journal of Economics, Finance and Management Sciences 10(2), 183-194.

[7] Grill and Zanalda (1995).Economic growth and the rise of service employment.NBER Working Paper No. 486.

[8] Hussian and Nadol (1997). The impact of economic growth on unemploymentinSouthAfrica:1994-2012. Investment Management and Financial Innovations, 13(1), 11-23.

[9] Jonathan, Anthony \& Emily (2015). Macroeconomic determinants of unemployment in Nigeria.

[10] NationalBureauofStatistics(2016).

Unemployment/underemployment watch Q1 2016. A quarterly publication of the National Bureau of Statistics, Abuja, Nigeria: Author.

[11] NationalBureauofStatistics(2018).Presentationoflabourstatisticsbas ed on revised concepts and methodology for computing labour
statisticsinNigeria.Availableatwww.nigerianstat.gov.ng/pages/dow nload/285.

[12] NationalBureauofStatistics(2018).Unemployment/underemployme nt watch Q1 2015. A quarterly publication of the National Bureau of Statistics. Abuja, Nigeria: Author.

[13] Nwaka, I. D., Uma, K. E. \& Tuna, G. (2015). Trade openness and unemployment: Empirical evidence for Nigeria. The Economic and Labour Relations Review 5, 1-20.

[14] Ogbanga, A. (2018). Agricultural development and employment generation in Nigeria. International Journal of Advanced Studies in Ecology, Development and Sustainability 5(1), 1-22.

[15] Ozughalu, U. M. \& Ogwumike, F. O. (2013). Can economic growth, foreign direct investment and exports provide the desired panacea to the problem of unemployment in Nigeria? Journal of Economics and Sustainable Development 4(1), 36 - 51 .

[16] Tregenna (2012). Macroeconomic variables and unemployment: The case of Turkey. International Journal of Economics and Financial Issues, 2(1), 71-78.

[17] Thirlwal (1979), The effect of unemployment rate on gross domestic product: Case of South Africa. Mediterranean Journal of Social Sciences, Published by MCSER-CEMAS-Sapienza UniversityofRome4(6),249-434. doi:10.5901/mjss.2013.v4n6p429.

[18] Yahaya, Y. \& Umar, B. (2017). Unemployment and economic growth dynamics: Evidence from business cycle model. Journal of Economics and Sustainable Development, 8(7), 7-19.

[19] Yilmaz, B. (2014). Effects of economic growth, export and foreign direct investment inflows on unemployment in Turkey (2010Q1:2013Q3). International Journal of Economics and Management Sciences2(8), 1-13 